\title{
A modern járművekben alkalmazott hajtásrendszerek áttekintése
}

\section{Review of Drive Systems Applied in Modern Vehicles}

\author{
A. SZÁNTó1 ${ }^{1}$ T. MANKOVITS² ${ }^{2}$ G. Á. SZÍKI ${ }^{3}$ \\ 1Ph.D. hallgató, Debreceni Egyetem, Műszaki Kar, Műszaki Alaptárgyi Tanszék, szanto.attila93@gmail.com \\ ${ }^{2}$ egyetemi docens, Debreceni Egyetem, Mǔszaki Kar, Gépészmérnöki Tanszék, tamas.mankovits@eng.unideb.hu \\ 3fóiskolai tanár, Debreceni Egyetem, Műszaki Kar, Műszaki Alaptárgyi Tanszék, szikig@eng.unideb.hu
}

\begin{abstract}
Absztrakt. Jelen közleményben áttekintjük a modern elektromos és hibrid rendszerú jármühajtásokat. Továbbá áttekintjük az azokban alkalmazott villanymotorok, akkumulátorok és üzemanyagcellák típusait, valamint a felépitésükkel és jellemző tulajdonságaikkal foglalkozó szakirodalmat. Továbbá, mivel a hibrid jármüvek fontos része a belsőégésü motor, áttekintjük azok hatékonyságának növelésére, valamint emissziójuk csökkentésére alkalmazott eljárásokat.
\end{abstract}

Kulcsszavak: elektromos és hibrid hajtás, akkumulátor, üzemanyagcella, modellezés és szimuláció.

Abstract. In this publication we review the drive systems of modern electric and hybrid vehicles. We also discuss the various types of electric motors, batteries, as well as fuel cell systems applied in them. Furthermore, as an important part of hybrid vehicles is the internal combustion engine, we review the literature about the methods used to.

\section{Bevezetés}

A Debreceni Egyetem Műszaki Karán már régóta foglalkozunk különböző elektromos és pneumatikus hajtású prototípus versenyautók, valamint hajtásláncok fejlesztésével, kivitelezésével. A hatékonyabb versenyzés érdekében a közelmúltban MATLAB/Simulink környezetben kifejlesztettünk egy járműdinamikai szimulációs programot, mellyel elvégezhetjük az egyes járművek menetdinamikai szimulációját különböző versenyszituációk esetén. A program segítségével optimalizálhatjuk a járművek és a hajtásláncok műszaki paramétereit egy adott versenyfeladatokhoz. A 'Tématerületi Kiválósági Program” „Debreceni Egyetemi (járműipari) tématerületi programja’ keretében a jövőben tervezzük a fenti szimulációs program kibővítését és továbbfejlesztését, hogy az közúti járművek, valamint hajtásláncok szimulációjára is alkalmas legyen. Ehhez mindenekelőtt fontos, hogy áttekintsük a jelenleg alkalmazott, korszerű járműhajtásokat, azok felépítését, a főbb részegységeik működését, típusait. Emellett megismerjük az egyes részegységek modellezésével és szimulációjával kapcsolatos szakirodalmakat, mely alapján kibővíthetjük, továbbfejleszthetjük a saját szimulációs programunkat. 


\section{Elektromos hajtásláncok}

A nagy energiahatékonyságú, alacsony karbantartási költségű és helyi emisszió mentes működésű elektromos motorok kiváló alternatívát jelentenek a jelenleg elterjedt hagyományos belső égésű (IC) motorok mellett. A technológiai fejlődés révén a különböző autógyárak fokozatosan le tudják küzdeni az elektromos járművek hagyományos hátrányait, egyre alkalmasabbá téve őket a mindennapi használatra [1]. Ennek eredményeként manapság többféle típusú elektromos motort használnak az elektromos vagy hibrid járművekben.

\subsection{Elektromos motorok}

Az [1] közleményben megtaláljuk a modern elektromos és hibrid jármúhajtások esetében alkalmazott különböző típusú villanymotorok, nevezetesen a kefés és kefe nélküli egyenáramú motor (BDC és BLDC), az indukciós (aszinkron) motor (IM), az állandó mágnesű szinkronmotor (SM), valamint a reluktanciamotor kapcsolóüzemű vezérléssel (SRM) leírását, összehasonlítását. Az összehasonlítás azon műszaki paraméterek alapján történik, amelyek figyelembevételével egy adott motor kiválasztható a különböző elektromos hajtású járművekhez. A fenti paraméterek táblázatok és grafikonok formájában szerepelnek a fenti irodalomban. A [2] közlemény a tisztán elektromos hajtású járművek hajtásláncaival foglalkozik. Megvizsgálja a különböző elektromos motorok előnyeit, hátrányait adott hajtásrendszerek esetén. Így kiválasztható az optimális motor egy adott alkalmazáshoz. A különböző típusú villanymotorok működését differenciálegyenletekkel tudjuk leírni, amelyek alapján felállítható a motor elektromágneses és dinamikai modellje. A modell alapján Matlab/Simulink környezetben - elkészíthető az egyes motortípusok szimulációja, amelyet beépíthetünk a korábban említett járműdinamikai szimulációs programunkba.

\subsection{Akkumulátorok}

Az akkumulátorok napjainkban széles körben elterjedtek, a technológia fejlődésének köszönhetően könnyen kezelhetők, és nagy mennyiségű energia tárolására alkalmasak, viszonylag kis helyen. Mára hozzájárulnak a mobiltelefonipar, a hordozható elektronika és számítástechnika, a robotika, valamint a járműipar fejlődéséhez. A jelen közleményben elsősorban a járműiparban alkalmazott, legelterjedtebb akkumulátor típusokkal foglalkozunk. Ezek a savas ólom (PbAc), a nikkel-fém-hidrid (NiMH), valamint a lítium-ion (Li-ion) akkumulátorok. 


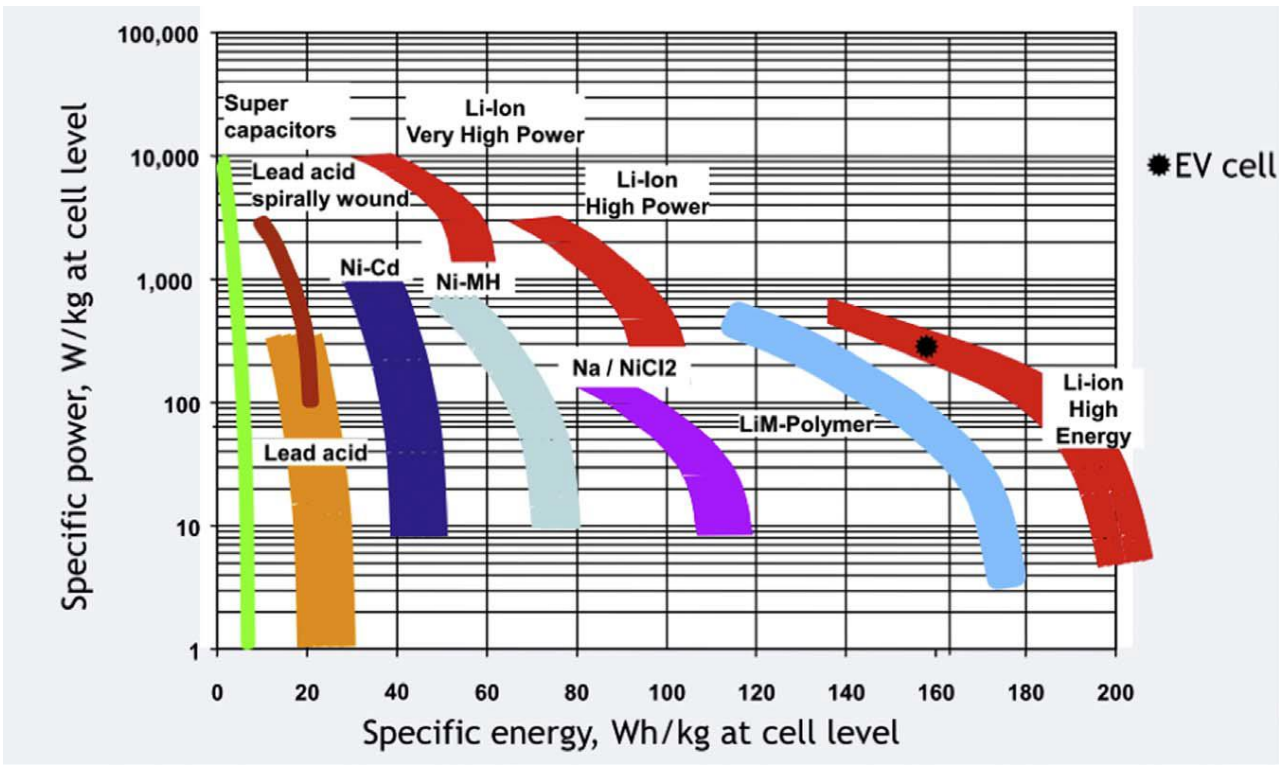

1. ábra. A legelterjedtebb akkumulátor típusok fajlagos energiája és teljesítménye [3]

A savas ólom akkumulátor biztosítja a belsőégésű motoros járművek indítását, gyújtását, elektromos és világító berendezéseinek múködését. Ahogy az 1. ábrán látható, ennek a típusnak relatíve alacsony a fajlagos energiája. [4] Amíg elektromos járművek esetén 200 km-es hatótávolság eléréshez közelítőleg 150 kg-os lítium-ion akkumulátor szükséges, addig ólom akkumulátorok esetében a szükséges tömeg több, mint 500 kg. Ebből adódóan az ólom akkumulátorok nem terjedtek el az elektromos hajtású járművekben. [3] A nikkel-fém-hidrid ( $\mathrm{NiMH}$ ) akkumulátorokat széles körben alkalmazzák hibrid hajtású járművekben (Pl. Toyota Prius), míg a tisztán elektromos hajtású járművekben leginkább a lítium-ion (Li-ion) akkumulátorok alkalmazása terjedt el. A járműipari alkalmazást korlátozó tényezők leginkább a méret és a tömeg, emiatt az autóipar folyamatosan olyan akkumulátor típust keres, amelynek nagyobb a fajlagos energiája és energia-sűrüsége. Továbbá fontos szempont a biztonságos használhatóság, az akkumulátor élettartama, valamint a megengedhető legnagyobb töltési sebesség. Tehát ez egy folyamatosan fejlődő terület, az elektromos járművek teljeskörű használhatóságának jelenleg leginkább az akkumulátorok szabnak határt.

\section{3. Üzemanyagcellák}

Az üzemanyagcella olyan energiaátalakító eszköz, amely egy reakció kémiai energiáját közvetlenül villamos energiává alakítja, miközben melléktermékként víz és hő keletkezik. Üzemanyaga és kialakítása szerint többféle típusú üzemanyagcella létezik, különböző hatásfokkal és működési hőmérséklettel. [5] A fenti szempontokat figyelembe véve, elektromos járművek hajtására csak a protoncsere membrános üzemanyagcella (PEMFC) használható. Ennek a működési hőmérséklete 50$100{ }^{\circ} \mathrm{C}$, míg hatásfoka 40-50\%, üzemanyaga pedig tiszta hidrogén. [6] Az üzemanyagcella nem közvetlenül a villanymotor(ok) számára termeli az elektromos áramok, hanem a rendszerbe egy kisebb méretű akkumulátor található, amit tölt. Fékezés esetén szintén ebbe az akkumulátorba táplál vissza a generátor. Üzemanyagcella alkalmazásával az elektromos hajtású járművek hatótávolsága általában nagyobb, mint a pusztán akkumulátoros típusoknál, valamint helyi emissziómentes működésűek. Ugyanakkor jelenleg több hátránnyal jár a technológia alkalmazása, mint előnnyel. A 
tiszta hidrogén előállítása, tárolása (kb. 700 Bar nyomás szükséges egy személyautó esetén), „tankolása” meglehetősen energiaigényes, és költséges. Továbbá, ha az egész rendszer hatásfokát vizsgáljuk (villanymotor, akkumulátor, üzemanyagcella, hidrogén előállítás stb.), akkor meglehetősen alacsony értéket kapunk (néhány százalék), ami nem tudja felvenni a versenyt más hajtástípusokkal.

\section{Hibrid hajtásláncok}

A hibrid hajtásláncok lényege, hogy több, különböző típusú hajtást, illetve energiatermelő rendszert alkalmaznak egy járműben. Maga az ötlet nem új, de napjainkban kezdtek csak igazán elterjedni a különböző hibrid rendszerek [7, 8], leginkább a környezetvédelmi előírások, és a hozzájuk kapcsolódó törvényi szabályozás miatt. Leggyakrabban valamilyen belsőégésű motoros hajtás van párosítva elektromos hajtással. Az elektromos hajtás bizonyos típusoknál csak rásegít a belsőégésű motorra, így csökkentve annak terhelését és üzemanyag fogyasztását, míg más típusoknál a jármű tisztán elektromos hajtással is közlekedhet. A konkrét technikai megoldásoknak számtalan változata van, amely gyártónkként, típusonként változik. A jelenlegi előrejelzések szerint a következő évtizedekben a különböző hibrid hajtású járművek kerülnek majd többségbe, ezért is fontos ezek, illetve egyes részegységeik vizsgálata.

\subsection{Modern belsőégésű motorok}

A belsőégésű motorok több mint 100 éves jelenlétük során évtizedről évtizedre folyamatosan fejlődtek. A technológiai fejlődés adta lehetőségeket kihasználva, a korszerű motorok hatásfoka már elérheti az 50\%-ot, míg emissziója csupán töredéke a 15-20 évvel ezelőtti értékeknek. Ezek olyan módszereknek köszönhetőek, mint a turbófeltöltő, közvetlen üzemanyag befecskendezés, változó szelepvezérlés, változó kompresszióviszony, kipufogógáz visszavezetés, alacsony hőmérsékletű égés, és egyéb technikai megoldások alkalmazása [9]. Emellett a különböző alternatív üzemanyagok [10] fejlesztése, használata szintén elősegíti a kibocsátott károsanyagmennyiség csökkentését. A tudomány jelen állása szerint a belsőégésű motorok még évtizedekig jelen lesznek a közúti közlekedésben, persze egyre inkább valamilyen elektromos hajtásrendszerrel kiegészítve.

\section{Összegzés}

A fentiekben áttekintettük a legelterjedtebb korszerű járműhajtásokat, illetve ezek főbb részegységeit. $\mathrm{Az}$ elektromos járművek esetén áttekintettük a korszerű hajtásrendszerekben alkalmazott villanymotor típusokat, a motorok energiaforrásaként szolgáló akkumulátorokat, valamint összefoglaltuk az üzemanyagcellákra vonatkozó ismereteket - melyek szintén a villanymotorok energiaforrásaként szolgálnak - különös tekintettel a járműiparban alkalmazott típusokra. Végül foglalkoztunk a napjainkban egyre inkább elterjedt hibrid hajtásrendszerekkel, valamint áttekintettük a korszerű belsőégésű motorokra vonatkozó ismereteket. 


\section{Köszönetnyilvánítás}

A tanulmány alapjául szolgáló kutatást az Innovációs és Technológiai Minisztérium által meghirdetett Tématerületi Kiválósági Program ED_18-1-2019-0028 számon támogatta, a Debreceni Egyetem (Járműipar) tématerületi programja keretében.

\section{Hivatkozások}

[1] Swaraj Ravindra Jape, Archana Thosar: Comparison of Electric Motors for Electric Vehicle Application, International Journal of Research in Engineering and Technology, Volume: 06 Issue: 09, September, 2017

[2] Juan de Santiago, et al.: Electrical Motor Drivelines in Commercial All-Electric Vehicles: A Review, IEEE TRANSACTIONS ON VEHICULAR TECHNOLOGY, VOL. 61, NO. 2, FEBRUARY 2012

[3] Amin Mahmoudzadeh Andwaria, et al.: A review of Battery Electric Vehicle technology and readiness levels. Elsevier: Renewable and Sustainable Energy Reviews 78 (2017) 414-430. http://dx.doi.org/10.1016/j.rser.2017.03.138

[4] Miller JM.: Energy storage system technology challenges facing strong hybrid, plug-in and battery electric vehicles. Veh Power Propuls Conference 2009. VPPC '09. IEEE; 2009. p. 4-10. http://dx.doi.org/10.1109/VPPC.2009.5289879.

[5] A. Kirubakaran, Shailendra Jain, R.K. Nema: A review on fuel cell technologies and power electronic interface. Renewable and Sustainable Energy Reviews 13 (2009) 2430-2440. Elsevier. doi:10.1016/j.rser.2009.04.004

[6] Yogesh Manoharan, Seyed Ehsan Hosseini, Brayden Butler et al.: Hydrogen Fuel Cell Vehicles; Current Status and Future Prospect. Appl. Sci. 2019, 9, 2296; doi:10.3390/app9112296

[7] C. Parag Jose, S. Meikandasivam: A Review on the Trends and Developments in Hybrid Electric Vehicles, Innovative Design and Development Practices in Aerospace and Automotive Engineering, Lecture Notes in Mechanical Engineering, 2017. DOI 10.1007/978-981-10-1771-1_25

[8] M.A.Hannan et.al.: Hybrid electric vehicles and their challenges: A review. Renewable and Sustainable Energy Reviews 29 (2014) 135-150. http://dx.doi.org/10.1016/j.rser.2013.08.097

[9] Noureddine Guellouh, Zoltán Szamosi, Zoltán Simenfalvi: Review of improvement methods of internal combustion engine efficiency. 2019. doi: 10.26649/musci.2019.040

[10] Choongsik Bae, Jaeheun Kim: Alternative fuels for internal combustion engines. Proceedings of the Combustion Institute 36 (2017) 3389-3413.

Elsevier. http://dx.doi.org/10.1016/j.proci.2016.09.009 